\title{
THE NUTRITIVE VALUES OF PUFA-CONCENTRATE SUPPLEMENTED WITH YEAST AND Curcuma xanthorrhiza Roxb STORED IN SEVERAL WEEKS
}

\author{
E. Sulistyowati ${ }^{1, *}$, A. Sudarman ${ }^{1}$, K. G. Wiryawan ${ }^{1}$ and T. Toharmat ${ }^{1}$ \\ ${ }^{1}$ Faculty of Animal Science, Bogor Agricultural University, \\ Jl. Agatis, IPB, Dramaga, Bogor 16680 - Indonesia \\ *Permanent Address: Faculty of Agriculture, University of Bengkulu, \\ Jl. Raya W.R. Supratman, Bengkulu 38371 - Indonesia \\ CorrespondingE-mail : ensulistyowati@yahoo.com
}

Received January 09, 2015; Accepted February 20, 2015

\begin{abstract}
ABSTRAK
Pakan konsentrat PUFA (polyunsaturated fatty acid) yang mengandung sumber asam lemak (jagung giling sangrai, kedelai sangrai, dan minyak jagung) ditetapkan sebagai konsentrat-PUFA untuk kambing perah. Ada empat macam konsentrat- PUFA, yaitu tanpa suplemen (PC0), 0,5\% atau $5 \mathrm{~g}$ ragi (PCY), 2\% atau $20 \mathrm{~g}$ tepung curcuma (PCC), dan $0.5 \%$ atau $5 \mathrm{~g}$ ragi dengan $2 \%$ atau $20 \mathrm{~g}$ tepung curcuma (PCM) ini dievaluasi kandungan nutrisi dan asam lemaknya selama penyimpanan 2, 4, dan 6 minggu. Aplikasi perlakuan dalam penelitian ini menggunakan rancangan acak acak lengkap dengan pengukuran berulang dan analisis data dengan split plot. Hasil menunjukkan bahwa kandungan bahan kering, bahan organik, ekstrak ether, protein kasar, bahan ekstratk tanpa $\mathrm{N}$, gross energy, acid detergent fiber, $\mathrm{Ca}$, $\mathrm{P}$, dan Saccharomyces cereviseae secara signifikan $(\mathrm{P}<0.05)$ stabil sebagai akibat dari tidak berubahnya kadar air pada konsentrat-PUFA dengan kombinasi suplemen pada penyimpanan 6 minggu. Total PUFA (P), rasio PUFA dan saturated fatty acid P/S, monounsaturated fatty acid (MUFA), dan kandungan long chained fatty acid cenderung tinggi pada konsentrat-PUFA dengan $20 \mathrm{~g}$ tepung curcuma. Konsentrat- PUFA dengan kombinasi $0,5 \%$ atau 5 g ragi dan $2 \%$ atau $20 \mathrm{~g}$ tepung curcuma banyak mengandung lemak unsaturated (U) dan rasio tinggi untuk dan rasio unsaturated fatty acid dan saturated fatty acid (U/S). Disimpulkan bahwa Kombinasi dari keseluruhan performans nutrisi selama penyimpanan 2 sampai 6 minggu, konsentrat-PUFA dengan $5 \mathrm{~g}$ ragi dan $20 \mathrm{~g}$ tepung curcuma dapat diertimbangkan sebagai konsentrat yang baik.
\end{abstract}

Kata kunci: fatty acid, konsentrat- PUFA, ragi, tepung curcuma

\begin{abstract}
The PUFA (polyunsaturated fatty acid)-concentrates containing fatty acid sources (roasted corn grain, roasted soy bean meal, and corn oil) was designated as PUFA- concentrate for dairy goat. There were four PUFA-concentrates, no supplement (PC0), $0.5 \%$ or $5 \mathrm{~g}$ yeast (PCY), $2 \%$ or $20 \mathrm{~g}$ curcuma powder (PCC), and $0.5 \%$ or $5 \mathrm{~g}$ yeast with $2 \%$ or $20 \mathrm{~g}$ curcuma powder (PCM). These PUFA-concentrates were evaluated for nutrients and fatty acid contents during 2, 4, and 6 weeks of storage. The application of treatments utilized in this research was completely randomized design with repeated measurement and split plot statistical analysis. Results showed that the contents of dry matter, organic matter, ether extract, crude protein, $\mathrm{N}$-free extract, gross energy, acid detergent fiber, $\mathrm{Ca}, \mathrm{P}$, and Saccharomyces cereviseae were significantly $(\mathrm{P}<0.05)$ remained stable as caused by unchained moisture of PUFA-concentrate with combined supplements (Y5C20) in the 6 weeks of storage. The total PUFA (P), P/S, monounsaturated fatty acid (MUFA), and long chained fatty acid contents tended to be high in PUFA-concentrate with $2 \%$ or $20 \mathrm{~g}$ curcuma powder. Whereas, the PUFA-concentrate with a combination of $0.5 \%$ or $5 \mathrm{~g}$ yeast and $2 \%$ or 20 g curcuma powder was higher in unsaturated $(\mathrm{U})$ fat and the ratio of U/S. In conclusion,
\end{abstract}


combining all nutrient performances during the storage of 2 to 6 weeks, the PUFA-concentrate with $0.5 \%$ or $5 \mathrm{~g}$ yeast and $2 \%$ or $20 \mathrm{~g}$ curcuma powder was considered nutritionally good.

Keywords: curcuma powder, fatty acid, PUFA-concentrate, yeast

\section{INTRODUCTION}

Concentrate feed is the main nutrient source for livestock, including dairy goat. Its nutritional values are importantly taken into account in order to fulfill the requirement for improved production and good quality of milk produced. Several feed supplements such as yeast have been applied extensively. It was reported as optimal level yeast in a rate of $3 \mathrm{~g}$ /dairy goat (Sulistyowati and Mega 2002), 20 g/dairy cow (Sulistyowati et al., 2010b), 56g/dairy cow (Hristov et al., 2010), and 50 g Rumisacc/ dairy cow (Yalçın et al., 2011). Yeast contain active viable cells, especially Saccharomyces cereviseae that would be beneficial for nutrient digestion through fermentation within the concentrate all the way to rumen system.

Herbs are considered as local plants medicine and as feed supplement. Temulawak (Javanese- Indonesian) or Curcuma xanthorrhiza Roxb as other Curcuma sp, containing curcuminoids (curcumin, demethoxycurcumin, and bisdemethoxycurcumin) is known for its biological activities, such as antioxidant, antiinflamantory, antimicrobial (Jayaprakasha et al., 2002). Supplementation of this curcuma powder of $15 \mathrm{~g} / \mathrm{kg}$ PUFA- concentrate increased milk production of dairy cow (Sulistyowati et al., 2010a) and $60 \mathrm{~g}$ curcuma diluent $/ 300 \mathrm{~g}$ Tabut block decreased total bacteria and fungi (Sulistyowati et al., 2008). Polyunsaturated fatty acid (PUFA) supplementation in ration is incompletely biohydrogenised later in the bio system of rumen which eventually will reduce fat, short and medium chain fatty acid into long chain fatty acid in milk (Whitlock et al., 2002; Schmidely et al., 2005). Concentrate with roasted ground corn, yeast, and curcuma powder showed optimal levels in PUFA, ratio of PUFA/saturated $(\mathrm{P} / \mathrm{S})$, and $\mathrm{n} 6 / \mathrm{n} 3$ designated for dairy cows (Sulistyowati et al., 2010a).

Dairy goat and its product are getting popular in terms of preference and nutrition for human health concern. Therefore, this research was designed to evaluate concentrate containing roasted corn grain, roasted soybean meal, and corn oil as PUFA sources supplemented with yeast and Curcuma xanthorrhiza Roxb, stored for

\section{2,4 , and 6 weeks.}

\section{MATERIALS AND METHODS}

\section{Feed Supplements Preparation}

Yeast supplement was prepared by modification on a procedure of Pusbangtepa (1981). In this research, the yeast was added as much as $0.5 \%$ or $5 \mathrm{~g} / \mathrm{kg}$ of PUFA-concentrate, mixed thoroughly. Curcuma supplement was prepared from $C$. xanthorrhiza Roxb tuber that was dried and grounded as powder. This curcuma powder contained $0.8 \%$ curcumin and $1.58 \%$ tannin (Sulistyowati et al., 2013). In this supplement, the curcuma powder was added as much as $2 \%$ or $20 \mathrm{~g} / \mathrm{kg}$ of PUFA-concentrate, mixed thoroughly.

\section{PUFA- Concentrate Preparation}

The PUFA- concentrate was designed for lactating dairy goat with $30 \mathrm{~kg}$ of body weight with the average of about $1 \mathrm{~kg}$ milk production (NRC, 1981). The composition and nutrient contents of PUFA-concentrates are presented in Table 1.

Ground corn was half roasted, while the soy bean meal was all roasted. As PUFA sources, they were containing $46.46 \%$ and $50.35 \%$, respectively. Cassava meal was prepared from the fresh tubers, chopped, dried, then was grounded as powder. Each supplement was then added accordingly for each treatment.

\section{Treatments and Experimental Design}

There were four treatments namely PC0: PUFA-concentrate with no supplementation; PCY: PUFA-concentrate with $5 \mathrm{~g}$ yeast; PCC: PUFA-concentrate with no yeast and $20 \mathrm{~g}$ curcuma; PCM: PUFA-concentrate with $5 \mathrm{~g}$ yeast and $20 \mathrm{~g}$ curcuma. These four PUFA-concentrates were then stored for 2,4 , and 6 weeks with three replications each. All together were 12 experimental units. The application of treatments utilized in this research was completely randomized design with repeated measurement and split plot statistical analysis. Analysis of variance with any differences were detected by Duncan multiple range test in significances of $\mathrm{P}<0.05$ and $\mathrm{P}<0.01$ according to Lentner and 
Table 1. Ingredient Composition of PUFA-Concentrate Supplemented with Yeast and C. xanthorrhiza Roxb

\begin{tabular}{lrrrr}
\hline \multicolumn{1}{c}{ Ingredients $(\% \mathrm{DM})$} & PC0 & PCY & PCC & PCM \\
\hline Rice bran & 35 & 35 & 35 & 35 \\
Ground corn $^{1}$ & 30 & 30 & 30 & 30 \\
Cassava meal $_{\text {Soy bean meal }}^{2}$ & 15 & 15 & 15 & 15 \\
Corn oil & 15 & 15 & 15 & 15 \\
Mineral mix & 4 & 4 & 4 & 4 \\
Yeast & 1 & 1 & 1 & 1 \\
Curcuma & - & 0.5 & - & 0.5 \\
\hline
\end{tabular}

PC0: PUFA-concentrate with no supplement; PCY: PUFA-concentrate with $5 \mathrm{~g}$ yeast; PCC: PUFAconcentrate with $20 \mathrm{~g}$ curcuma; PCM:PUFA-concentrate with $5 \mathrm{~g}$ yeast and $20 \mathrm{~g}$ curcuma; ${ }^{1}$ half roasted; ${ }^{2}$ all roasted.

Bishop (1986).

\section{Analysis of Feed}

Nutrient analyses of dry matter, crude protein $(\mathrm{CP})$, crude fiber $(\mathrm{CF})$, and ether extract (EE) were determined according to AOAC (2000). The content of NFE was calculated as $100 \%$ - (moisture + ash + EE + CP + CF). The contents of NDF and ADF were determined by the method of Goering and Van Soest (1970). Minerals of $\mathrm{Ca}$ and $\mathrm{P}(\lambda=660 \mathrm{~nm})$ were analyzed using atomic absorbance spectrophotometer (AAS).

Bioactive analyses of curcumin was determined by maceration of $500 \mathrm{~g} \quad C$. xanthorrhiza Roxb in $96 \%$ ethanol for 48 hours (Sutrisno et al., 2008). Tannin was analyzed by extracting $3 \mathrm{~g}$ of sample in boiling water, then was determined its color using Spectrophotometer.

Microbial analyses for bacteria population was counted by NA (nutrient agar) plate, and fungi analysis was conducted with the same procedure, except it was inoculated onto PDA (potato dextrose agar).

Fatty acid methyl esters (FAME) were obtained using gas chromatography (GC) Shimadzu 2010 series. There are several calculations of total short chain fatty acid (C4$\mathrm{C} 10)$, medium chain fatty acid (C12-C16), long chain fatty acid $(C>16)$, mono unsaturated, poly unsaturated, saturated, unsaturated, ratio of PUFA/saturated, and unsaturated/saturated fatty acid. Fatty acid ratio of n-6/n-3 was calculated using this formula (Schmidely et al., 2005 ):

$$
n 6 / n 3=\frac{\text { linoleic acid }+ \text { arachidonic acid }}{\text { linolenic acid }}
$$

While, atherogenicity score was calculated with this formula (Ulbrict and Southgate 1991):

$$
\text { Atherogenicity index }=\frac{(\mathrm{C} 12+4 \mathrm{C} 14+\mathrm{C} 16)}{\text { total unsaturated fat }}
$$

The index is an indicator of short fatty acid that will be converted in milk then may cause cardiovascular desease for the consumer. These all analyses were conducted in week 2, 4, and week 6 of the storage of PUFA-concentrate.

\section{RESULTS AND DISCUSSION}

\section{Moisture, Dry and Organic Matter}

The dry and organic matters of PUFAconcentrate supplemented with yeast and $C$. xanthorrhiza Roxb stored for 2 to 6 weeks are presented in Table 2. Most of the concentrates were higher in moisture $(16.38 \%)$, lower in dry matter $(-2.05 \%)$, and lower in organic matter ($2.81 \%)$ significantly $(\mathrm{P}<0.05)$ during 6 weeks of storage, compared to those in week 2 and week 4 in three treatments, except PUFA-concentrate supplemented with yeast and C. xanthorrhiza Roxb (PCM).

These relationships showed that the longer the concentrates stored in anaerobic condition, the higher the water absorbed, therefore the moisture was increasing and at the same time the dry and organic matter were decreasing. However, the 
Table 2. Moisture, Dry Matter, Organic Matter, and Ash Contents in PUFA-Concentrate Supplemented with yeast and C. xanthorrhiza Roxb Stored for 2-6 Weeks

\begin{tabular}{|c|c|c|c|c|c|}
\hline Nutrient & $\mathrm{PC} 0$ & PCY & $\mathrm{PCC}$ & PCM & Average \\
\hline \multicolumn{6}{|l|}{ Moisture (\%) } \\
\hline 2 weeks & $8.46^{\mathrm{x}}$ & $8.78^{\mathrm{x}}$ & $8.79^{\mathrm{x}}$ & 8.79 & $8.70^{\mathrm{X}}$ \\
\hline 4 weeks & $8.24^{\mathrm{x}}$ & $8.48^{\mathrm{x}}$ & $8.41^{\mathrm{x}}$ & 8.16 & $8.32^{\mathrm{X}}$ \\
\hline 6 weeks & $11.16^{\mathrm{y}}$ & $10.77^{\mathrm{y}}$ & $11.41^{\mathrm{y}}$ & 8.78 & $10.53^{\mathrm{Y}}$ \\
\hline Average & 9.29 & 9.35 & 9.53 & 8.58 & \\
\hline \multicolumn{6}{|l|}{ Dry matter (\%) } \\
\hline 2 weeks & $91.54^{\mathrm{x}}$ & $91.22^{\mathrm{x}}$ & $91.22^{\mathrm{x}}$ & 91.21 & $91.30^{\mathrm{XY}}$ \\
\hline 4 weeks & $91.77^{\mathrm{x}}$ & $91.52^{x}$ & $91.59^{x}$ & 91.84 & $91.68^{\mathrm{x}}$ \\
\hline 6 weeks & $88.84^{\mathrm{y}}$ & $89.23^{\mathrm{y}}$ & $88.60^{\mathrm{y}}$ & 91.22 & $89.47^{\mathrm{Y}}$ \\
\hline Average & 90.71 & 90.65 & 90.47 & 91.42 & \\
\hline \multicolumn{6}{|l|}{ Organic matter (\%) } \\
\hline 2 weeks & $84.66^{\mathrm{x}}$ & $84.56^{\mathrm{x}}$ & $84.87^{\mathrm{x}}$ & 84.58 & $84.67^{\mathrm{x}}$ \\
\hline 4 weeks & $85.20^{\mathrm{x}}$ & $84.21^{\mathrm{x}}$ & $84.65^{\mathrm{x}}$ & 84.79 & $84.71^{\mathrm{x}}$ \\
\hline 6 weeks & $81.89^{\mathrm{yab}}$ & $82.45^{\mathrm{yb}}$ & $80.52^{\mathrm{ya}}$ & $84.38^{\mathrm{c}}$ & $82.31^{\mathrm{Y}}$ \\
\hline Average & $83.91^{\mathrm{AB}}$ & $83.74^{\mathrm{A}}$ & $83.35^{\mathrm{A}}$ & $84.58^{\mathrm{B}}$ & \\
\hline
\end{tabular}

Different superscript in a row $(a, b, c)$ or within column $(\mathrm{x}, \mathrm{y}, \mathrm{z})$, different significantly $(\mathrm{P}<0.05)$. PC0: PUFAconcentrate with no supplement; PCY: PUFA-concentrate with 5g yeast; PCC: PUFA-concentrate with $20 \mathrm{~g}$ curcuma; PCM:PUFA-concentrate with $5 \mathrm{~g}$ yeast and $20 \mathrm{~g}$ curcuma.

PUFA-concentrate supplemented with yeast and C. xanthorrhiza Roxb (PCM) seemed to remain stable in moisture, dry matter, ash, and organic matter composition during the storage of 2,4 , and 6 weeks. In spite of these facts, this treatment was showing significantly $(\mathrm{P}<0.05)$ lowest moisture $(8.78 \%)$, highest dry matter $(91.22 \%)$, and the highest organic matter $(84.38 \%)$ in 6 weeks of storage compared to those in week 2 of storage among treatments. Based on these data, the PUFA-concentrate supplemented with yeast and C. xanthorrhiza Roxb (PCM) with the highest organic matter is considered the most sustained along with this period of storage (6 weeks). This meant that supplementation of yeast and curcuma powder stabilized moisture, dry and organic matters of the PUFA-concentrates.

Moisture content of the PUFA-concentrate would be another important reason for the reduction in colony forming unit later. This is in conjunction with data on the viability of the cells, that it showed an opposite relationship when the lowest moisture happened in the 6 weeks of storage resulted in the highest concentration of Saccharomyces cereviseae as shown in PUFAconcentrate supplemented with yeast and $C$. xanthorrhiza Roxb (PCM). Increasing water availability and high temperature will activate yeast cells that eventually will be ceased because of inadequate available nutrients (Sullivan and Bradford, 2011).

Results in this experiment approved this statement that dry matter and organic matters were decreasing with higher moisture content in the PUFA-concentrate with no supplements, yeast, or curcuma only, resulting in eventually lowering concentrations of Saccharomyces cereviseae.

\section{Ether Extract, Crude Protein, and Gross Energy}

Other nutrients, such as crude protein, $\mathrm{N}$-free extract (NFE), and gross energy in PUFAconcentrate supplemented with yeast and $C$. xanthorrhiza Roxb were significantly affected 
within 2 to 6 weeks of storage (Table 3). However, ether extract contents in week-2 of PC0 $(8.96 \%)$, PCY $(8.41 \%)$, and PCC $(8.98 \%)$ were significantly higher $(\mathrm{P}<0.05)$ than those in week6. While, in PCM concentrate, its ether extract was remained relatively the same during 2 to 6 weeks storage.

However, this concentrate showed the lowest ether extract in the 2 weeks storage. The crude fiber and NFE of 2 and 4 weeks storage were higher significantly $(\mathrm{P}<0.05)$ than that of in 6 weeks. Reductions were quantitatively found in crude protein $(-8.01 \%)$ and gross energy (-6.65\%) within 6 weeks of storage of all PUFAconcentrates. These data suggested that the longer the PUFA-concentrates (with or without yeast and

Table 3. Ether Extract, Crude Protein, Crude Fiber, N-Free Extract, and Gross Energy Contents in PUFA-Concentrate Supplemented with Yeast and C. xanthorrhiza Roxb Stored for 2-6 weeks

\begin{tabular}{|c|c|c|c|c|c|}
\hline Nutrient & $\mathrm{PC} 0$ & PCY & PCC & PCM & Average \\
\hline \multicolumn{6}{|l|}{ Ether extract (\%) } \\
\hline 2 weeks & 8.96 & 8.41 & 8.98 & 8.17 & 8.63 \\
\hline 4 weeks & 8.09 & 8.28 & 9.05 & 9.05 & 8.62 \\
\hline 6 weeks & 8.10 & 8.14 & 8.56 & 8.33 & 8.28 \\
\hline Average & 8.38 & 8.28 & 8.86 & 8.51 & \\
\hline \multicolumn{6}{|l|}{ Crude protein $(\%)$} \\
\hline 2 weeks & 12.26 & 12.00 & 11.79 & 11.60 & 11.91 \\
\hline 4 weeks & 11.54 & 11.65 & 11.69 & 11.58 & 11.62 \\
\hline 6 weeks & 11.86 & 11.27 & 11.76 & 11.32 & 11.55 \\
\hline Average & 11.89 & 11.64 & 11.74 & 11.50 & \\
\hline \multicolumn{6}{|l|}{ Crude fiber (\%) } \\
\hline 2 weeks & $13.51^{\mathrm{x}}$ & 13.30 & 13.14 & 13.48 & $13.36^{\mathrm{X}}$ \\
\hline 4 weeks & $12.91^{\mathrm{xy}}$ & 12.83 & 13.06 & 12.88 & $12.92^{\mathrm{XY}}$ \\
\hline 6 weeks & $12.57^{\mathrm{y}}$ & 12.15 & 12.64 & 12.12 & $12.37^{\mathrm{Y}}$ \\
\hline Average & 13.00 & 12.76 & 12.95 & 12.83 & \\
\hline \multicolumn{6}{|l|}{ NFE $(\%)$} \\
\hline 2 weeks & $49.94^{\mathrm{x}}$ & 50.85 & $50.96^{\mathrm{x}}$ & 51.33 & $50.77^{\mathrm{XY}}$ \\
\hline 4 weeks & $52.66^{\mathrm{y}}$ & 51.45 & $50.85^{\mathrm{x}}$ & 51.28 & $51.56^{\mathrm{x}}$ \\
\hline 6 weeks & $49.36^{\mathrm{xab}}$ & $50.89 b^{c}$ & $47.57^{\mathrm{ya}}$ & $52.60^{\mathrm{c}}$ & $50.11^{\mathrm{Y}}$ \\
\hline Average & $50.65^{\mathrm{A}}$ & $51.07^{\mathrm{AB}}$ & $49.79^{\mathrm{B}}$ & $51.74^{\mathrm{B}}$ & \\
\hline \multicolumn{6}{|c|}{ Gross energy $(\mathrm{kcal} / \mathrm{g})$} \\
\hline 2 weeks & 4124 & 4091 & 3986 & 4378 & 4145 \\
\hline 4 weeks & 3992 & 4067 & 3946 & 4023 & 4007 \\
\hline 6 weeks & 3974 & 3825 & 3752 & 3915 & 3867 \\
\hline Average & 4030 & 3994 & 3895 & 4105 & \\
\hline
\end{tabular}

Different superscript in a row $(\mathrm{a}, \mathrm{b}, \mathrm{c})$ or within column $(\mathrm{x}, \mathrm{y}, \mathrm{z})$, different significantly $(\mathrm{P}<0.05)$. PC0: PUFA -concentrate with no supplementation; PCY: PUFA -concentrate with $5 \mathrm{~g}$ yeast; PCC: PUFA-concentrate with $20 \mathrm{~g}$ curcuma; PCM:PUFA-concentrate with $5 \mathrm{~g}$ yeast and $20 \mathrm{~g}$ curcuma. 
curcuma supplementation) stored, the less nutritional values shown.

In conjunction with these facts, that the average moisture content was increasing while the organic and dry matters were decreasing; consequently, other nutritional contents within the organic matter such as ether extract, crude fiber, crude protein, and gross energy were found diminishing as well. This suggested that during storage, fermentation process was happening where nutrients were broken down significantly. These carbon contents in the nutrients were being taken up for microbial growth, such as it happened in coincidence with higher population of Saccharomyces sp (2.35 $\left.10^{7} \mathrm{cfu} / \mathrm{g}\right)$ and
Bacillus sp $\left(11.4310^{7} \mathrm{cfu} / \mathrm{g}\right)$ as presented in Table 6.

\section{Neutral Detergent Fiber, ADF, Ca, and $P$}

Within 2 weeks of storage, NDF and ADF contents of all PUFA-concentrates were not significantly different (Table 4). Only ADF was affected, in week 2 and 4 were higher $(p<0.05)$ than that of during 6 weeks of storage. In this week, PUFA-concentrate without any supplement (PC0) showed the lowest NDF (65.27\%) and the highest ADF (33.95\%). While, the lowest ADF $(22.54 \%)$ contained in PUFA-concentrate with both supplements (PCM). In all treatments, the differences between week- 2 and week- 6 of

Table 4. Neutral Detergent Fiber, ADF, Ca, and P Contents in PUFA-concentrate Supplemented with Yeast and C. xanthorrhiza Roxb Stored for 2-6 weeks

\begin{tabular}{|c|c|c|c|c|c|}
\hline Nutrient & $\mathrm{PC} 0$ & PCY & PCC & PCM & Average \\
\hline \multicolumn{6}{|l|}{ NDF $(\%)$} \\
\hline 2 weeks & 74.85 & 71.70 & 71.62 & 70.17 & 72.09 \\
\hline 4 weeks & 67.38 & 74.05 & 66.11 & 70.31 & 69.46 \\
\hline 6 weeks & 65.27 & 71.22 & 69.79 & 69.01 & 68.82 \\
\hline Average & 69.17 & 72.32 & 69.17 & 69.83 & \\
\hline \multicolumn{6}{|l|}{$\operatorname{ADF}(\%)$} \\
\hline 2 weeks & $25.16^{\mathrm{x}}$ & 24.73 & 23.84 & 25.37 & $24.78^{\mathrm{x}}$ \\
\hline 4 weeks & $36.38^{y}$ & 30.47 & 27.06 & 29.13 & $30.76^{\mathrm{Y}}$ \\
\hline 6 weeks & $33.95^{\mathrm{xy}}$ & 25.16 & 24.06 & 22.54 & $26.43^{\mathrm{XY}}$ \\
\hline Average & $31.83^{\mathrm{B}}$ & $26.78^{\mathrm{A}}$ & $24.99^{\mathrm{A}}$ & $25.68^{\mathrm{A}}$ & \\
\hline \multicolumn{6}{|l|}{$\mathrm{Ca}(\%)$} \\
\hline 2 weeks & 0.38 & 0.36 & 0.44 & 0.47 & 0.41 \\
\hline 4 weeks & 0.59 & 0.57 & 0.70 & 0.74 & 0.65 \\
\hline 6 weeks & 0.52 & 0.53 & 0.57 & 0.60 & 0.56 \\
\hline Average & 0.50 & 0.49 & 0.57 & 0.60 & \\
\hline \multicolumn{6}{|l|}{$\mathrm{P}(\%)$} \\
\hline 2 weeks & 0.66 & 0.62 & 0.61 & 0.63 & 0.63 \\
\hline 4 weeks & 0.45 & 0.55 & 0.60 & 0.61 & 0.55 \\
\hline 6 weeks & 0.64 & 0.67 & 0.64 & 0.75 & 0.68 \\
\hline Average & 0.58 & 0.61 & 0.62 & 0.66 & \\
\hline
\end{tabular}

Different superscript in a row $(a, b, c)$ or within column $(x, y, z)$, different significantly $(\mathrm{P}<0.05)$. PC0: PUFA -concentrate with no supplementation; PCY: PUFA -concentrate with 5g yeast; PCC: PUFA-concentrate with $20 \mathrm{~g}$ curcuma; PCM: PUFA-concentrate with $5 \mathrm{~g}$ yeast and $20 \mathrm{~g}$ curcuma. 
storages were found in NDF (-4.89\%), ADF (4.35\%), Ca (32.84), and $\mathrm{P}(7.23 \%)$.

In overall, all three treated PUFAconcentrates were lower $(\mathrm{P}<0.05)$ in $\mathrm{ADF}$ compared to that of in control diet. Suggesting that yeast, curcuma, and their combination worked well in reducing fiber that is soluble in acid. The PCM was considered the most nutritional since it showed significantly $(\mathrm{P}<0.05)$ the lowest ADF with the highest $\mathrm{Ca}$ and $\mathrm{P}$. Other study showed that basal diet for dairy cows in which $56 \mathrm{~g}$ XP yeast incorporated, was having $31 \% \mathrm{NDF}, 20.4 \% \mathrm{ADF}, 0.96 \% \mathrm{Ca}$, and $0.39 \% \mathrm{P}$ (Hristov et al., 2010). Compared to this research data, the NDF and P were more than doubled, while $\mathrm{Ca}$ was one third of those in XP diet.

\section{Tannin and Curcumin}

Bio actives detected in the $C$. xanthorrhiza Roxb used in this experiment were $0.8 \%$ curcumin and $1.58 \%$ tannin. Tannin levels in four treatments of PUFA-concentrate quantitatively were decreasing as much as $32.78 \%$ in 6 weeks storage compared to those in 2 weeks storage (Table 5). Among the treatments, PUFAconcentrate with no supplements (PC0) quantitatively contained the lowest tannin; while PUFA-concentrate with yeast and curcuma supplements (PCM) had the highest one during 26 weeks of storage. This suggested that curcuma powder contributed some amount of tannin in the concentrate. Tannins in all type of concentrate found in this study were not as high as it was in polyherbal combination (3.69\%) as reported by Mirzaei and Prasad (2011).

Curcumin levels in both treatments, PCC and PCM were found the same in week 2 , yet decreasing in week 6; however, it was slightly higher in PCM. These results showed that tannin and curcumin concentrations were found not as much high as than those in their original sources when other feedstuffs were combined together and depended upon its level added as well. Curcuminoids in $C$. longa contained curcumin (1.06-5.65\%), demethoxycurcumin $(0.83-3.36 \%)$, and bisdemethoxycurcumin $(0.42-2.16 \%)$ as observed by Jayaprakasha et al. (2002).

\section{Microbial Viability}

This self made yeast contained $3.610^{7} \mathrm{cfu} / \mathrm{g}$ (Sulistyowati et al., 2013). The viable cell was within the range of other commercial yeast products $\left(2.9310^{7}-1.4310^{13} \mathrm{cfu} / \mathrm{g}\right)$ that had been surveyed by Sullivan and Bradford (2011). They reported that there was a decrease in the viability of the cell approximately $90 \%$ per month when the active dry yeast was kept under high temperature of $40^{\circ} \mathrm{C}$; however, there was no significant difference of viable cells stored during spring and summer as the variability of the

Table 5. Tannin and Curcumin Contents in PUFA-Concentrate Supplement with Yeast and $C$. xanthorrhiza Roxb Stored for 2-6 Weeks

\begin{tabular}{rccccc}
\hline Bioactive & PC0 & PCY & PCC & PCM & Average \\
\hline Tannin (\%) & & & & & \\
2 weeks & 0.23 & 0.27 & 0.29 & 0.30 & 0.27 \\
4 weeks & 0.20 & 0.20 & 0.19 & 0.19 & 0.20 \\
6 weeks & 0.17 & 0.18 & 0.24 & 0.24 & 0.21 \\
Average & 0.20 & 0.22 & 0.24 & 0.24 & \\
Curcumin (\%) & & & & & \\
2 weeks & - & - & 0.10 & 0.10 & 0.10 \\
4 weeks & & & 0.06 & 0.06 & 0.06 \\
6 weeks & - & - & 0.07 & 0.09 & 0.08 \\
Average & & & 0.08 & 0.08 & \\
\hline
\end{tabular}

PC0: PUFA-concentrate with no supplement; PCY: PUFA-concentrate with $5 \mathrm{~g}$ yeast; PCC: PUFAconcentrate with $20 \mathrm{~g}$ curcuma; PCM: PUFA-concentrate with $5 \mathrm{~g}$ yeast and $20 \mathrm{~g}$ curcuma. 
samples were so wide due to different distribution.

In this research, the yeast was prepared in the ambient temperature of around $31{ }^{\circ} \mathrm{C}$ (in Bengkulu) then added into PUFA-concentrate and kept in another ambient temperature of around $26.94^{\circ} \mathrm{C}$ with average moisture of $78.83 \%$ (in Ciapus, upper land of Bogor). These regions were certainly lower in the ambient temperature compared to the temperature of other research result.

Results in Table 6 showed that Saccharomyces sp was significantly $(\mathrm{P}<0.05)$ higher $\left(20.6810^{6} \mathrm{cfu} / \mathrm{g}\right)$ in 6 weeks compared to those in 2 weeks $(2.30 \mathrm{cfu} / \mathrm{g})$ of storage. However, there were no significant differences among PUFA-concentrates in Saccharomyces $s p$ population. The population of viable cell in the yeast seemed to be well protected by the addition of curcumin in the concentrate, while it was stored under suitable ambient temperature. This kind of supplements would be beneficial for ruminants.

Bacillus sp were not significantly different during 2, 4, and 6 weeks of storage. However, diet with combination of yeast and curcuma (PCM) in 4 weeks showed the highest $(\mathrm{P}<0.05)$ Bacillus $\mathrm{sp}$ $\left(28.7310^{6} \mathrm{cfu} / \mathrm{g}\right)$. This happens as there was yeast that could increase the availability of nutrient; together with nutrient available from curcuma then made this diet as a good source of Bacillus $\mathrm{sp}$ as well as Saccharomyces sp to grow more than that in separated supplement diets.

The populations of $S$. cereviseae and Bacillus sp in Tabut block (300 g), a feed supplement block, containing $20 \%$ curcuma diluents and 35\% yeast-fermented cassava stored in 12 weeks, were reported decreasing (Sulistyowati et al., 2008). Further study showed that Saccharomyces cereviseae supplementation was reported to increase organic matter digestibility generating a higher energy availability for milk yield in buffalos (Campanile et al., 2008).

\section{Fatty Acids Profile}

Fatty acid methyl esters (FAME) contents in these PUFA-concentrates (Table 7 and Table 8) were showing specific amount even though they contained the same level and sources of PUFA (roasted ground corn, roasted soy bean meal, and corn oil).

This might represent the presence of yeast and curcuma or their combination in reaction with fatty acid content in concentrate during the bio hydrogenation reaction. Total fatty acid of PUFAconcentrate with $20 \mathrm{~g}$ curcuma (PCC) seemed to be the highest $(79.25 \%)$, while the one without

Table 6. Microbes Population in PUFA-Concentrate Supplemented with Yeast and C. xanthorrhiza Roxb Stored for 2-6 Weeks

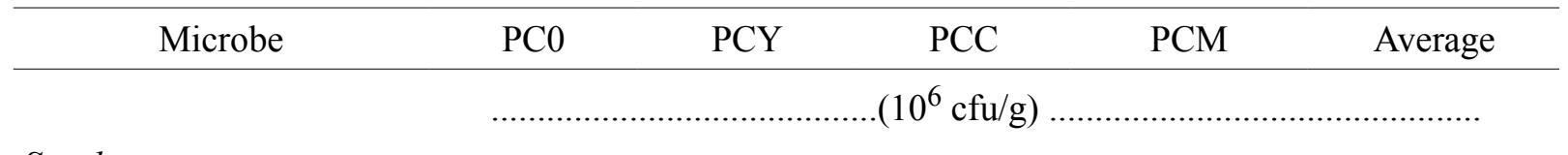

Saccharomyces sp

$\begin{array}{lccccc}2 \text { weeks } & 1.57^{\mathrm{x}} & 1.20^{\mathrm{x}} & 2.43^{\mathrm{x}} & 4.00^{\mathrm{x}} & 2.30^{\mathrm{X}} \\ 4 \text { weeks } & 0.07^{\mathrm{x}} & 1.03^{\mathrm{x}} & 0.43^{\mathrm{x}} & 5.87^{\mathrm{x}} & 1.85^{\mathrm{x}} \\ 6 \text { weeks } & 18.83^{\mathrm{y}} & 19.77^{\mathrm{y}} & 20.63^{\mathrm{y}} & 23.50^{\mathrm{y}} & 20.68^{\mathrm{Y}} \\ \text { Average } & 6.82 & 7.33 & 7.83 & 11.12 & \end{array}$

Bacillus sp

$\begin{array}{lccccc}2 \text { weeks } & 6.93 & 3.67 & 0.37 & 9.20 & 5.04 \\ 4 \text { weeks } & 5.90^{\mathrm{a}} & 2.90^{\mathrm{a}} & 1.93^{\mathrm{a}} & 28.73^{\mathrm{b}} & 9.87 \\ \text { 6 weeks } & 19.47 & 8.43 & 7.87 & 11.43 & 11.80 \\ \text { Average } & 10.77^{\mathrm{AB}} & 5.00^{\mathrm{A}} & 3.39^{\mathrm{A}} & 16.46^{\mathrm{B}} & \end{array}$

Different superscript in a row $(\mathrm{a}, \mathrm{b}, \mathrm{c})$ or within column $(\mathrm{x}, \mathrm{y}, \mathrm{z})$, different significantly $(\mathrm{P}<0.05)$. PC0: PUFAconcentrate with no supplement; PCY: PUFA-concentrate with 5g yeast; PCC: PUFA-concentrate with $20 \mathrm{~g}$ curcuma; PCM: PUFA-concentrate with 5 g yeast and 20 g curcuma. 
supplement (PC0) was the lowest (33.74\%), in 2 weeks of storage. In the 6 weeks of storage, the same treatment (PCC) showed the highest total fatty acid $(62.64 \%)$, while the PUFA-concentrate with $5 \mathrm{~g}$ yeast and $20 \mathrm{~g}$ curcuma (PCM) had the lowest total fatty acid (46.54\%). This described that curcumin only, with the amount of 0.07$0.10 \%$ in PUFA-concentrate would be optimal in hydrogenation process such that it would yield the highest total fatty acid.

As shown in the highest total fatty acid, polyunsaturated fatty acid (PUFA) was also found the highest in concentrate with $20 \mathrm{~g}$ curcuma, both in 2 weeks $(41.77 \%)$ and 6 weeks (24.07\%) of storage. Obviously, fatty acid was decreasing with the longer time of storage. The total PUFA of PUFA-concentrate with yeast was almost twice $(29.25 \%)$ as it was in PUFA-concentrate with no supplements in 2 weeks of storage. This, in part, could be described that yeast in commercial yeastRumiSacc contained PUFA (26.42\%) that might contribute to the total PUFA of concentrate or diet as reported by Yalçın et al. (2011). Previous results study (Sulistyowati et al., 2010a) of concentrate containing $5 \mathrm{~g}$ yeast, $15 \mathrm{~g}$ curcuma powder, with palm oil, corn oil, and roasted ground corn showed that total PUFA was ranging from $77.23 \%$ (in $1.5 \%$ corn oil and 3\% roasted ground corn) to $79.19 \%$ (in $4.5 \%$ palm oil). These are about 2- 3 times higher than the results in the present experiment.

The fatty acid profile of PCC was considered the highest among other treatments; C18:2 (38.47\% of total FA), C18:1 (27.02\%), and lower levels of $\mathrm{C} 18: 3(3.24 \%)$ and $\mathrm{C} 18: 0(0.05 \%)$ in 2 weeks. In 6 weeks, PCC was still showing the highest fatty acid profile; C18:1 (21.94\%), C18:2 (21.88\%), $\mathrm{C} 18: 3$ and $\mathrm{C} 18: 0$ were lower. Curcumin in this concentrate containing corn oil, roasted soy bean meal, and roasted corn, seemed to be able to protect unsaturated fat from further hydrogenation. This is more in positive way since there is no fermentation effect from yeast in this treatment, so that it would not cause a certain level of rancidity that might lead to hydrogenation of much more unsaturated fat. Fatty acids were also detected in soy bean oil that the highest contents were found in C18:2 (54\%) and C18:1 (22\%) (Bouattour et al., 2008).

In accordance with the highest total PUFA in 2 and 6 weeks of storage; medium (MCFA) and long chain fatty acid (LCFA) as well as monounsaturated fatty acid (MUFA) were found to be the highest in the same PUFA-concentrate with curcuma (PCC). Saturated (S) fatty acid increased gradually (from $6.93 \%$ to $12.42 \%$ ) with the more completed supplement. In contrast, the unsaturated (U) fatty acid decreased in that manner during the 2 weeks storage. During 6 weeks of storage, this trend worked the other way, PUFA-concentrate with yeast and curcuma (PCM) showed the lowest saturated fat $(28.49 \%)$ with the highest unsaturated fatty acid (71.51\%).

Ratio of $\mathrm{P} / \mathrm{S}$, ratio $\mathrm{U} / \mathrm{S}, \mathrm{n} 6 / \mathrm{n} 3$, and atherogeneicity of all treatments in 2 weeks compared to those in 6 weeks of storage were quantitatively down or up in the averages of $-81.94 \%, \quad-80.37 \%, \quad 15.74 \%$, and $221.74 \%$, respectively. The $\mathrm{P} / \mathrm{S}$ ratio and $\mathrm{n} 6 / \mathrm{n} 3$ ratio in the previous experiment with similar treatment showed $3.7 \%$ and $1.59 \%$ in average, respectively (Sulistyowati et al. 2010a). Only the $\mathrm{P} / \mathrm{S}$ ratio in 2 week storage that was close to this; whereas, the n6/n3 was 8-9 times higher in this current research. The ratio of $\mathrm{n} 6 / \mathrm{n} 3$ in the 2 weeks (12.71) and 6 weeks (14.59) were much higher than those in soy bean oil (4.69- 6.12), reported by Bouattour et al. (2008). These ratios in PUFA-concentrate were far above the recommended range of $n 6 / n 3$ for human wise is between 5:1 and 10:1. However, the $n 6 / n 3$ ratio in the milk of dairy goat fed diet containing this PUFA-concentrate with combined supplements was 5.82 while the diet containing this PUFA-concentrate with yeast was 11 (Sulistyowati et al., 2013). For a comparison, the ratio of $\mathrm{P} / \mathrm{S}$ were 0.88 and 1.69 , respectively in saturated fat (prilled hydrogenated fat) containing diets and unsaturated fat (Ca soaps of long chain fatty acid) as reported by Harvatine and Allen (2006). These suggested that the type of fat supplemented in concentrate would determine its type of fatty acid. Different PUFA are not secreted freely from each other, therefore, any other vegetable oil as supplement would respond differently in its fatty acid content (Chilliard et al., 2006).

The atherogeneicity index increased in PUFA-concentrate with the more complete supplement in 2 weeks (Table 7); on the other hand, it decreased in PUFA-concentrate with the same treatment in 6 weeks of storage (Table 8). This index supposedly dealing with unhealthy saturated fat that might lead to some kind of blood vessel disease (Ulbricht and Southgate, 1991). However, other researchers (Mensink et al., 2003; Knopp and Retzlalaff 2004, Chilliard et al., 2006; Bouattour et al., 2008) declared that there is little fact that the medium chain fatty acid (C12:0, 
Table 7. Fatty Acid Contents in PUFA-Concentrate Supplemented with Yeast and C. xanthorrhiza Roxb Stored for 2 Weeks

\begin{tabular}{lrrrrr}
\hline \multicolumn{1}{c}{ Fatty Acid (\%) } & PC0 & PCY & PCC & PCM & SEM \\
\hline Total Fatty acid & 33.74 & 55.54 & 79.25 & 70.52 & 19.92 \\
Total SCFA (C4- C10) & nd & nd & nd & 0.05 & - \\
Total MCFA (C12- C16) & 5.38 & 6.78 & 9.42 & 11.39 & 2.69 \\
Total LCFA (C>C16) & 28.39 & 48.78 & 69.82 & 59.08 & 17.65 \\
Total MUFA & 11.52 & 17.54 & 27.18 & 27.02 & 7.66 \\
Total PUFA(P) & 15.27 & 29.25 & 41.77 & 31.08 & 10.89 \\
Total Saturated fat (S) & 6.93 & 8.77 & 10.29 & 12.42 & 2.33 \\
Total Unsaturated (U) & 93.07 & 91.23 & 89.71 & 87.58 & 2.33 \\
Rasio P/S & 2.20 & 3.34 & 4.06 & 2.50 & 0.84 \\
Rasio U/S & 13.44 & 10.40 & 8.72 & 7.05 & 2.73 \\
n6/n3 & 13.48 & 11.52 & 11.86 & 13.96 & 1.19 \\
Atherogenicity & 0.06 & 0.08 & 0.11 & 0.14 & 0.03 \\
\hline
\end{tabular}

PC0: PUFA-concentrate with no supplement; PCY: PUFA-concentrate with 5 g yeast; PCC: PUFAconcentrate with $20 \mathrm{~g}$ curcuma; PCM: PUFA-concentrate with $5 \mathrm{~g}$ yeast and $20 \mathrm{~g}$ curcuma; SEM: Standard error means

Table 8. Fatty Acid Contents in PUFA-Concentrate Supplemented with Yeast and C. xanthorrhiza Roxb Stored for 6 Weeks

\begin{tabular}{lrrrrr}
\hline \multicolumn{1}{c}{ Fatty Acid (\%) } & PC0 & PCY & PCC & PCM & SEM \\
\hline Total Fatty acid & 58.85 & 58.13 & 62.64 & 46.54 & 6.95 \\
Total SCFA (C4- C10) & 0.04 & 0.04 & 0.03 & 0.03 & 0.01 \\
Total MedCFA (C12- C16) & 18.35 & 19.11 & 15.75 & 11.85 & 3.28 \\
Total LongCFA (C>C16) & 39.94 & 38.64 & 46.61 & 34.45 & 5.04 \\
Total MUFA & 15.85 & 14.86 & 21.93 & 16.32 & 3.19 \\
Total PUFA(P) & 17.55 & 16.39 & 24.07 & 17.84 & 3.46 \\
Total Saturated fat (S) & 40.78 & 41.4 & 38.32 & 28.49 & 5.99 \\
Total Unsaturated (U) & 59.22 & 58.6 & 61.68 & 71.51 & 5.99 \\
Ratio - P/S & 0.43 & 0.4 & 0.63 & 0.63 & 0.12 \\
Ratio- U/S & 1.45 & 1.42 & 1.61 & 2.51 & 0.52 \\
Ratio n6/n3 & 14.50 & 15.43 & 14.10 & 14.32 & 0.59 \\
Atherogenicity & 0.31 & 0.33 & 0.26 & 0.17 & 0.07 \\
\hline
\end{tabular}

PC0: PUFA-concentrate with no supplement; PCY: PUFA-concentrate with $5 \mathrm{~g}$ yeast; PCC: PUFAconcentrate with $20 \mathrm{~g}$ curcuma; PCM: PUFA-concentrate with $5 \mathrm{~g}$ yeast and $20 \mathrm{~g}$ curcuma; Nd: not detected; SEM: standard error means 
C14:0, and C16:0) caused in atherogenic effect. This saturated fat is even better compared to high carbohydrate with low fat; and it would be of concern only if fat consumption is excessive. The average index in this experiment was 0.10 and 0.27 during the 2 and 6 weeks of storage, respectively. These could be considered as low levels in the feed that will be healthy for ruminants and eventually into their product that will be beneficial for human health.

\section{CONCLUSION}

The PUFA-concentrate with mix supplements (curcuma and yeast) showed highest organic matter, nitrogen free extract, and Saccharomyces sp population in 6 weeks of storage and highest acid detergent fiber in 4 weeks. The higher contents of PUFA, ratio of PUFA to saturated, MUFA, and long chained fatty acid were shown by PUFA-concentrate with $2 \%$ or $20 \mathrm{~g}$ curcuma. In overall nutrient composition, supplementation of $0.5 \%$ or $5 \mathrm{~g}$ yeast in combination with $2 \%$ or $20 \mathrm{~g}$ curcuma in PUFAconcentrate designed for dairy goat is considered as a reasonable effort to maintain its nutritive performance during 6 weeks of storage.

\section{ACKNOWLEDGEMENT}

The authors gratefully acknowledge Directorate General for Higher Education (DGHE) for financially support this project through HIBAH STRANAS - IPB in the year of 2013. High appreciation was also extended to Ir. Sigit Mujiharjo MSAE for checking statistical analysis. The data in this present study was part of the overall research. Thanks were also extended to Cordero Farm owner and workers as well as several students who had been very helpful during the research in Bogor.

\section{REFERENCES}

AOAC. 2000. Official methods of analysis. $17^{\text {th }}$ Ed. Association of Official Analytical Chemists. AOAC International.Maryland. Chapter 4. Pp. 1-41.

Bouattour, M.A., R. Casas, E. Albanell, X. Such and G. Caja. 2008. Feeding soybean oil to dairy goats increases conjugated linoleic acid in milk. J. Dairy Sci. 91:2399-2407.

Campanile, G., F. Zicarelli, D. Vecchio, C. Pacelli, G. Neglia, A. Balestrieri, R. Di Palo and F. Infascelli. 2008. Effects of Saccharomyces cereviseae on ivivo organic matter digestibility and milk yield in buffalo cows. Livest. Sci. 114:358-361.

Chilliard, Y., J. Rouel, A. Ferlay, L. Bernard, P. Gaborit, K. Raynal-Ljutovac, A. Lauret and C. Leroux. 2006. Optimising goat milk and cheese fatty acid composition. Pages 281282 in Improving the Fat Content of Foods. C. Williams and J. Buttriss, ed. Woodhead Publishing Limited, Cambridge, UK.

Goering, H.K. and P.J. Van Soest. 1970. Forage fiber analysis. Agricultural Handbook No: 379. USDA. Agricultural Research Service. Washington DC, pp. 1-9.

Harvatine, K.J. and M.S. Allen. 2006. Effects of fatty acid supplements on milk yield and energy balance of lactating dairy cows. J. Dairy Sci. 89: 1081- 1091.

Hristov, A.N., G. Varga, T. Cassidy, M. Long, K. Heyler, S.K.R Karnati, B. Corl, C.J. Hovde and I. Yoon. 2010. Effect of (Saccharomyces cerevisiae) fermentation product on ruminal fermentation product on ruminal fermentation and butrient utilization in dairy cows. J. Dairy Sci. 93:682- 692.

Jayaprakasha, G.K., L.J.M. Rao and K.K. Sakariah. 2002. Improved HPLC Method for the determination of curcumin, demethoxycurcumin, and bisdemethoxycurcumin. J. Agric. Food. Chem. 50: 3668- 3672.

Knopp, R.H. and B.M. Retzlaff. 2004. Saturated fat prevents coronay disease? An American paradox. Am. J. Clin. Nutr. 80: 1102- 1103.

Lentner, M. and T. Bishop. 1986. Experimental Design and Analysis. Valley Book Co. VA.

Mensink, R.P., P.L. Zock, A.D.M. Kester and M.B. Katan. 2003. Effects of dietary fatty acids and carbohydrates on the ratio of serum total to HDL cholesterol and on serum lipids and apoliproteins: A metaanalysis of 60 controlled trials. Am. J. Clin. Nutr. 77: 1146-1155.

Mirzaei, F. and S. Prasad. 2011. Influence of dietary phytoadditive as polyherbal combination on performance of does and respective litters in cross bred dairy goats. Asian-Aust. J. Anim. Sci. 21(10):1386-1392.

NRC (National Research Council). 1981. Nutrient Requirements of Goats: Angora, Dairy, and Meat Goats in Temperate and Tropical Countries. National Academy Press. Washington, DC. US. 
Pusbangtepa. 1981. Ragi Tape. Pusat Penelitian dan Pengembangan Teknologi Pangan. FTDC-IPB. Bogor. Indonesia.

Schmidely, P., P. Morand-Fehr, and D. Sauvant. 2005. Influence of extruded soybeans with or without bicarbonate on milk performance and fatty acid composition of goat milk. J. Dairy Sci. 88:757-765.

Sulistyowati, E. and O. Mega. 2002. Suplementasi ragi dalam konsentrat nabati terhadap konsumsi nutrisi kambing perah. Prosiding Seminar Nasional Bidang Ilmu Pertanian BKS-PTN Barat. 11-12 June. Medan (ID).

Sulistyowati, E, U. Santoso, I. Badarina, H. Bustaman, M. Mayarini and R. Oktarina. 2008. Effects of different temulawak (Curcuma xanthorriza Roxb) levels on the microbiology of Tabut Block. Proceeding: Management Strategy of Animal Health and Production Control on Anticipation of Global Warming for Achievement of Millenium Development Goals. Pp: 161164. Fac. of Veterinary Medicine, UNAIR and Fac. of Veterinary Medicine, UPM. 3- 4 June. Surabaya (ID).

Sulistyowati E, I. Badarina and U. Santoso. 2010a. Milk production and modification of milk fatty acid of dairy cows fed PUFAconcentrate. J. Indonesian Trop. Anim. Agric. 35 (4): 262-267.

Sulistyowati E, I. Badarina and E. Soetrisno. 2010b. Supplementation of Starbio probiotic and yeast on milk production and nutrient digestibility of lactating Holstein cows fed a ration containing cassava meal. J. Dairy Sci.
93. E- Suppl. 1: 860.

Sulistyowati, E., A. Sudarman, K.G. Wiryawan and T. Toharmat. 2013. Quality of milk fatty acid during late lactation in dairy goat fed on PUFA-diet supplemented with yeast and Curcuma xanthorrhiza Roxb. J. Indonesian Trop. Anim. Agric. 38(4):247- 256.

Sullivan, M.L. and B.J. Bradford. 2011. Viable cell yield from active dry yeast products and effect of storage temperature and diluents on yeast viability. J. Dairy Sci. 94:526-531.

Sutrisno, D. Sukarianingsih, M. Saiful, A. Putrika and D.I. Kusumaningtyas. 2008. Curcuminoids from Curcuma xanthorrhiza Roxb: isolation, characterization, identification. Proceedings of the First International Symposium on Temulawak. IICC. Bogor (ID). May 27- 29.

Ulbricht, T.L.V. and D.A.T Southgate. 1991. Coronary heart disease: Seven dietary factors. Lancet. 338:985-992.

Whitlock, L.A, D.J. Schingoethe, A.R. Hippen, K.F. Kalscheur, R.J. Baer, N. Ramasmy and K.M. Kasperson. 2002. Fish oil and extruded soybeans fed in combination increase conjugated linoleic acids in milk of dairy cows more than fed separately. J. Dairy Sci 85:234-243.

Yalçın S., C. Pınar, O. Arif, Gürdal, C. Bağcı and O. Eltan. 2011. The nutritive value of live yeast culture (Saccharomyces cerevisiae) and its effect on milk yield, milk composition and some blood parameters of dairy cows. Asian-Aust. J. Anim. Sci. 24 (10):1377-1385 